\title{
PENGEMBANGAN LKPD BERDASARKAN INVENTARISASI CAPUNG UNTUK MENGUKUR KETERAMPILAN PROSES DASAR PESERTA DIDIK KELAS X IPA 2 SMA N 7 BENGKULU UTARA
}

\author{
Rani Hidayanti ${ }^{1 *}$, Irwandi Ansori ${ }^{1}$, Yennita Yennita ${ }^{1}$ \\ Program Studi Pendidikan Biologi, Fakultas Keguruan dan Ilmu Pendidikan, Universitas Bengkulu \\ Email: hidayantirani97@gmail.com
}

\begin{abstract}
Abstrak
Penelitian ini bertujuan untuk mengetahui kelayakan Lembar Kerja Peserta Didik (LKPD) yang dikembangkan berdasarkan inventarisasi capung untuk mengukur keterampilan proses dasar peserta didik. Subjek penelitian adalah peserta didik kelas X IPA ${ }^{2}$ SMA Negeri 7 Bengkulu Utara. Teknik pengumpulan data dalam penelitian ini adalah angket (kuesioner) dengan instrumen yang digunakan berupa lembar angket (kuesioner) untuk tiga orang validator (dua orang dosen pendidikan Biologi Universitas Bengkulu dan satu orang guru Biologi SMA N 7 Bengkulu Utara) dan lembar keterbacaaan untuk peserta didik. Berdasarkan hasil validasi oleh validator LKPD yang disusun memperoleh hasil persentase rata-rata skor $88 \%$ (kategori sangat layak) dan 98,5\% dalam uji keterbacaan oleh 27 peserta didik kelas X IPA ${ }^{2}$ SMA N 7 Bengkulu Utara. Berdasarkan hasil tersebut dinyatakan bahwa desain LKPD yang disusun layak digunakan sebagai bahan ajar materi Keanekaragaman Hayati.
\end{abstract}

Kata kunci: Capung, Inventarisasi, Pengembangan LKPD.

\begin{abstract}
This research aimed to determined the feasibility of Student Worksheets (LKPD) developed based on the study of inventory of dragonflies to measure the skills of the basic process of grade $10^{\text {th }}$ students in Senior High School 7 North Bengkulu. The subject of this study were students of grade $10^{\text {th }}$ Senior High School 7 North Bengkulu. Technique of collecting data in this research was questionnaire with instrument was questionnaire sheets for 3 validators and legibility sheets for students. According to validation results by validators, developed Student Worksheets was obtained score $88 \%$ for linguistics aspect (Very Good) and According to readability test by 27 students in Senior High School 7 North Bengkulu, the design of developed Student Worksheets was obtained score $96 \%$ (Good). Based on the results, it was concluded that developed Student Worksheets was useable as teaching material for Biodiversity topic at $10^{\text {th }}$ grade of Senior High School.
\end{abstract}

Keywords: Dragonflies, Inventory, Student Worksheets.

\section{PENDAHULUAN}

Pembelajaran Biologi dalam kegiatan pembelajaran digunakan sebagai alat pendidikan yang berguna untuk mencapai tujuan pembelajaran. Kegiatan pembelajaran Biologi diharapkan dapat memberikan pengetahuan terkait nilainilai Biologi bagi peserta didik ataupun guru sebagai pendidik. Berbagai jenis pengetahuan yang dimaksud dalam proses pembelajaran adalah pengetahuan dasar dari prinsip dan konsep yang bermanfaat dalam kehidupan sehari-hari baik peserta didik ataupun guru sebagai pendidik (Shelly, 2017).

Guru sebagai seorang pendidik memiliki peran sangat penting dalam pelaksanaan pembelajaran. Oleh sebab itu, guru harus kompeten dalam menciptakan aktivitas pembelajaran peserta didik agar sesuai dengan aspek pengembangan, pengetahuan, keterampilan dan sikap (Asy'ari, 2006). Penggunaan bahan ajar dapat mendukung proses pembelajaran dan salah satu contohnya adalah Lembar Kerja Peserta Didik (LKPD). LKPD merupakan sumber belajar yang dapat dikembangkan oleh guru sebagai fasilitator untuk menunjang kegiatan pembelajaran di kelas (Widjajanti, 2008). Selain itu, alasan penggunaan LKPD dalam proses pembelajaran adalah nilai kepraktisannya yang dapat membantu peserta didik ataupun guru dalam memahami konsep Bilogi (Trianto, 2012). 
LKPD dapat dikembangkan berdasarkan pada studi lingkungan sekitar, sehingga akan lebih mudah bagi peserta didik untuk memahami materi yang dipelajari, salah satunya pada materi keanekaragaman hayati khususnya keanekaragaman jenis capung di kawasan Sungai Sebelat, hal ini sesuai dengan Rosalia (2017) mengatakan bahwa pembelajaran menggunakan LKPD dapat memberikan pengalaman langsung pada peserta didik, karena peserta didik dapat mencari informasi dan mendapatkan konsep materi dengan sendirinya, dengan cara mengikuti prosedur yang ada di dalam LKPD.

Penggunaan LKPD dalam pembelajaran Biologi diharapkan dapat meningkatkan keaktifan, kreatifitas dan inovatif peserta didik dalam kegiatan pembelajaran. LKPD yang dapat menunjang peningkatan dalam proses pembelajaran adalah LKPD yang sesuai dengan tujuan pencapaian pada suatu kompetensi dasar, serta dapat mencerminkan keterampilan proses sains peserta didik sesuai dengan pendekatan sainstifik, sehingga dalam pengembangannya LKPD tersebut perlu disusun dengan mempertimbangkan penggunaan sumber belajar yang relevan (Majid, 2009).

Berdasarkan hasil observasi dan wawancara di SMA N 7 Bengkulu Utara, terdapat beberapa kendala yang dihadapi oleh guru dan peserta didik saat proses pembelajaran berlangsung, salah satunya pada materi keanekaragaman hayati. Peserta didik terkadang sering mengalami rasa jenuh di awal pembelajaran, hal ini disebabkan karena materi keanekaragaman hayati hanya sebatas pengetahuan konsep. Selain itu, contoh yang sering diberikan jauh berbeda dengan keadaan lingkungan sehari-hari dan kurang memiliki kebermaknaan bagi peserta didik. Ketersediaan LKPD yang didesain dari sumber belajar lingkungan sekitar peserta didik diharapkan mampu menunjang aktivitas belajar peserta didik menjadi lebih baik, khususnya dalam mengembangkan pada ranah keterampilan proses dasar peserta didik. Menurut Sanjaya (2012) sumber belajar adalah segala sesuatu yang ada di lingkungan kegiatan belajar mengajar yang dapat digunakan secara fungsional agar dapat terwujud hasil belajar yang diinginkan.

Berdasarkan penjelasan di atas, peneliti melakukan penelitian di kawasan Sungai Sebelat, dengan tujuan untuk melihat keanekaragaman jenis capung yang terdapat di lokasi penelitian. Kemudian, dalam penelitian ini akan dilakukan uji coba LKPD kepada peserta didik SMA N 7 Bengkulu Utara berdasarkan inventarisasi capung di kawasan Sungai Sebelat yang digunakan untuk mengukur keterampilan proses dasar peserta didik. Sebelum dilakukan uji coba LKPD terlebih dahulu LKPD hasil pengembangan divalidasi oleh validator yang terdiri dari validator ahli media, validator ahli materi dan validator ahli guru Biologi SMA N 7 Bengkulu Utara.

\section{METODE}

Metode yang digunakan dalam penelitian adalah metode Research and Development (R\&D), penelitian ini dilaksanakan pada bulan Desember-Maret 2019 di SMA N 7 Bengkulu Utara. Subjek penelitian ini adalah 27 peserta didik Kelas $X$ IPA 2 SMA N 7 Bengkulu utara. Teknik pengumpulan data menggunakan lembar angket (kuesioner) yang terdiri atas angket uji kelayakan dan angket uji keterbacaan oleh peserta didik. Adapun data hasil uji kelayakan dan uji keterbacaan dianalisis menggunakan rumus sebagai berikut:

$$
P=\frac{\sum x}{\sum x i} x 100 \%
$$




\section{Keterangan}

$\begin{array}{ll}P & \text { : Persentase Kevalidan } \\ 100 \% & \text { : Konstanta } \\ \Sigma \mathrm{xi} & \text { : Jumlah nilai ideal per-item } \\ \Sigma \mathrm{X} & : \text { Jumlah jawaban responden } \\ & \text { per-item }\end{array}$

Hasil persentase tersebut akan diinterpretasikan dengan menggunakan panduan tabel kriteria interpretasi skor uji validitas seperti Tabel 1.

Tabel 1. Kriteria Kevalidan Data Hasil Penilaian

\begin{tabular}{lll}
\hline \multicolumn{1}{c}{ Tingkat Persentase (\%) } & \multicolumn{1}{c}{ Kriteria } & \multicolumn{1}{c}{ Keterangan } \\
\hline $81,25-100$ & Sangat Valid & Layak/ tidak revisi \\
$62,50-81,24$ & Valid & Cukup Layak/ tidak revisi \\
$43,75-62,49$ & Kurang valid & Kurang layak/ revisi sebagian \\
$25-43,74$ & Sangat kurang valid & Tidak layak/ revisi total \\
\hline
\end{tabular}

Riduwan (2015)

Hasil belajar keterampilan setiap kelompok akan analisa menggunakan rumus :

$$
\text { nilai }=\frac{\text { Skor yang diperoleh }}{\text { skor maksimal }} \times 4
$$

(Anas, 2012)

Rentang skor pada tiap indikator disesuaikan dengan rubrik penilaian keterampilan proses, yaitu skor 4 (Sangat baik), skor 3 (baik), skor 2 (cukup), 1 (kurang). Sehingga, jumlah skor maksimum dan minimum ialah :

Skor maksimum : 5 indikator $\times 4=20$

Skor minimum : 5 indikator $\times 1=5$

Untuk menghitung hasil belajar keterampilan proses secara klasikal menggunakan rumus rerata yaitu :

$$
\text { Rata-rata nilai: } \sum \mathrm{X}=\frac{X}{{ } r}
$$

Keterangan:

$$
\begin{array}{ll}
\Sigma \mathrm{X} & \text { : Nilai rata-rata } \\
\mathrm{X} & \text { : Jumlah nilai yang diperoleh } \\
\mathrm{N} & \text { : Jumlah peserta didik }
\end{array}
$$

(Anas, 2012)

Setelah skor rerata keterampilan secara klasikal diperoleh. Selanjutnya, dilakukan penentuan tingkat ketuntusan hasil belajar keterampilan proses dasar peserta didik yang mengacu pada penilaian III Permendikbud No. 104 Tahun 2014 Kurikulum 2013 dapat dilihat pada Tabel 2.

Tabel 2. Tingkat Ketuntasan Hasil Belajar Keterampilan Proses Dasar

\begin{tabular}{cccc}
\hline Tingkat Ketuntasan & Persentase ketuntasan & Rentang Skor & Predikat \\
\hline Tuntas & $\geq 90 \%$ & $3,85-4,00$ & $\mathrm{~A}$ \\
& & $3,51-3,84$ & $\mathrm{~A}-$ \\
& & $3,18-3,50$ & $\mathrm{~B}+$ \\
& & $2,85-3,17$ & $\mathrm{~B}$ \\
& & $2,51-2,84$ & $\mathrm{~B}-$ \\
Tidak Tuntas & & $2,18-2,50$ & $\mathrm{C}+$ \\
& & $1,85-2,17$ & $\mathrm{C}$ \\
& & $1,51-1,84$ & $\mathrm{C}-$ \\
& & $1,18-1,50$ & $\mathrm{D}+$ \\
\hline
\end{tabular}

(Permendikbud, 2014)

Kriteria ketuntasan minimal untuk ranah keterampilan pada pembelajaran
Biologi kelas X SMA N 7 Bengkulu Utara adalah 2,75 dengan predikat B-. 
HASIL DAN PEMBAHASAN

Tabel 3. Persentase Validasi LKPD oleh Validator

\begin{tabular}{cllcc}
\hline No & \multicolumn{1}{c}{ Validator } & Aspek Penilaian & Presentase & Kriteria Respon \\
\hline 1 & Dosen Biologi 1 & Kegrafisan (Media Ajar) & $93 \%$ & Sangat Valid \\
2 & Dosen Biologi 2 & Materi dan Kebahasaan & $82,6 \%$ & Sangat Valid \\
3 & Guru & Materi dan Kebahasaan & $88,4 \%$ & Sangat Valid \\
& & Rata-rata persentase & $88 \%$ & Sangat Valid
\end{tabular}

Berdasarkan Tabel 3 diketahui bahwa secara kualitatif hasil validasi LKPD menunjukan kriteria respon "sangat valid" artinya kriteria respon sangat valid menunjukan bahwa LKPD layak diujicobakan ke peserta didik dengan hasil review oleh dosen Biologi dari setiap aspek yakni 93\% untuk aspek kegrafisan (media ajar) dengan kriteria respon sangat valid dan $82,6 \%$ untuk aspek materi dan kebahasaan dengan kriteria respon sangat valid. Untuk persentase review dari guru Biologi pada aspek materi dan kebahasaan adalah sebesar $88,4 \%$ dengan kriteria respon sangat valid. LKPD hasil pengembangan dikatakan layak jika data hasil validasi menunjukan persentase rerata $\geq 75 \%$. Setelah dilakukan validasi, peneliti melakukan revisi sesuai dengan saran dari validator, hal ini sesuai dengan Widarmayanti (2015) yang mengatakan
Berdasarkan penelitian yang telah dilakukan persentase validator dapat dilihat pada Tabel 3.

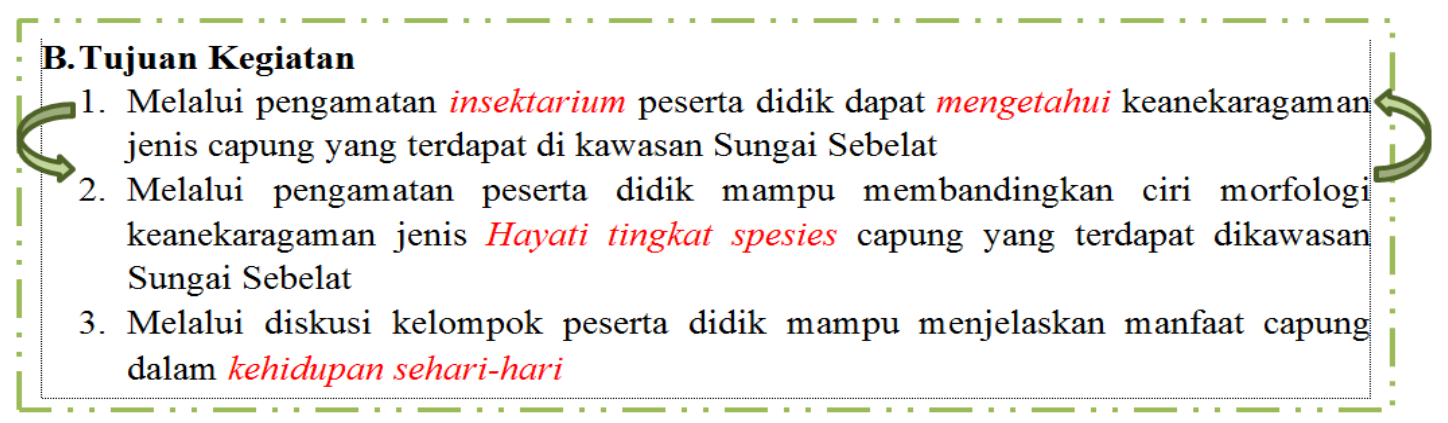

Tujuan Sebelum Revisi 


\section{B. Tujuan Kegiatan}

1. Melalui pengamatan peserta didik mampu membandingkan ciri morfologi" keanekaragaman jenis capung yang terdapat di kawasan Sungai Sebelat

2. Melalui pengamatan awetan capung peserta didik dapat mengidentifikasi " keanekaragaman jenis capung yang ter dapat di kawasan sungai Sebelat

3. Melalui diskusi kelompok peserta didik mampu menjelaskan manfaat keberadaan " capung dalam suatu ekosistem

\section{Tujuan Setelah Revisi}

\section{G. Pertanyaan}

1. Berdasarkan tabel hasil pengamatan, deskripsikanlah ciri morfologi dari masing-masing capung sub-ordo Anisoptera dan capung sub-ordo Zygoptera? (Penambahan kata bandingkan dan sebelum kata deskripsikanlah)

\section{G. Pertanyaan}

\section{Pertanyaan Sebelum Revisi}

1. Berdasarkan tabel hasil pengamatan, deskripsikanlah ciri morfologi dari capung sub-ordo Anisoptera dan capung sub-ordo Zygoptera ?

\section{Pertanyaan Setelah Revisi}

Gambar 1. Gambar Sesudah dan Sebelum Perbaikan Susunan Kalimat Sesuai SPOK

2) Perhatikan kalimat dalam prosedur kerja pada lembar LKPD yang sesuai. Adapun prosedur penelitian bermanfaat dalam membimbing peserta didik dalam melakukan praktikum atau kegiatan pembelajaran (langkah kerja). Berikut ditampilkan gambar sesudah dan sebelum revisi pada Gambar 2.

\section{E. Cara Kerja}

1. Bacalah cara kerja pengamatan dengan cermat

2. Amatilah 8 Jenis awetan capung (insektarium) dengan teliti meliputi morfologi mata, bentuk tubuh dan: struktur abdomen serta morfologi sayap capung.

- Pada pengamatan morfologi mata capung, amatilah dan bandingkan dengan gambar bentuk mata yang tersedia pada lembar identifikasi.

- Pada pengamatan tubuh capung, amati bentuk dan warna tubuh capung serta bandingkan dengan gambar tubuh capung yang tersedia pada lembar identifikasi dan ukurlah penjang tubuh capung: menggunakan mistar

- Pada pengamatan bentuk sayap, amatilah dan bandingkan dengan gambar yang terdapat pada lembar identifikasi.

3. Catatlah hasil pengamatan pada tabel pengamatan!

4. Diskusikan hasil pengamatan dan jawablah pertanyaan analisis yang disediakan.

5. Buatlah kesimpulan bersama kelompokmu! 


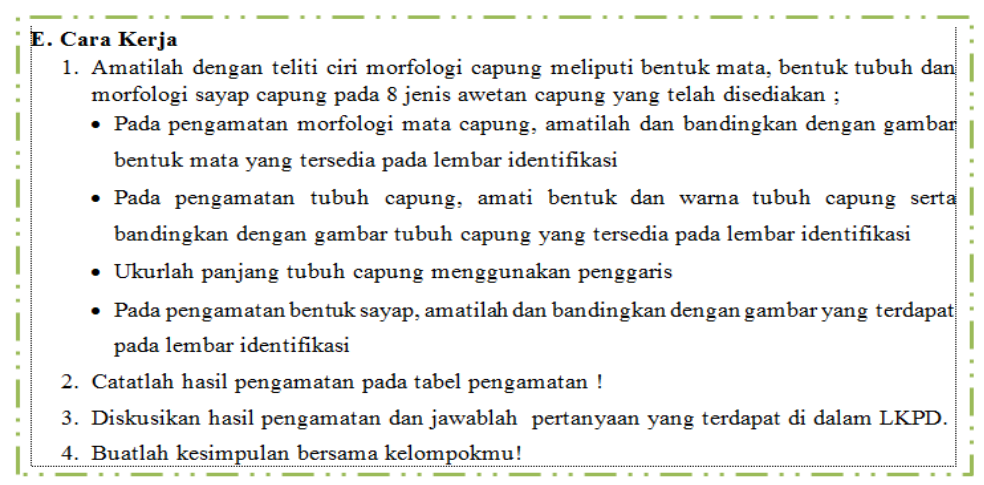

\section{Prosedur Kerja Setelah Revisi}

Gambar 2. Cara Kerja Sebelum dan Sesudah Revisi

3) Perbaikan tampilan Lampiran, bertujuan agar dapat memudahkan peserta didik dalam mengidentifikasi jenis capung yang disediakan peneliti dalam bentuk insektarium, ditampilkan pada Gambar 3.
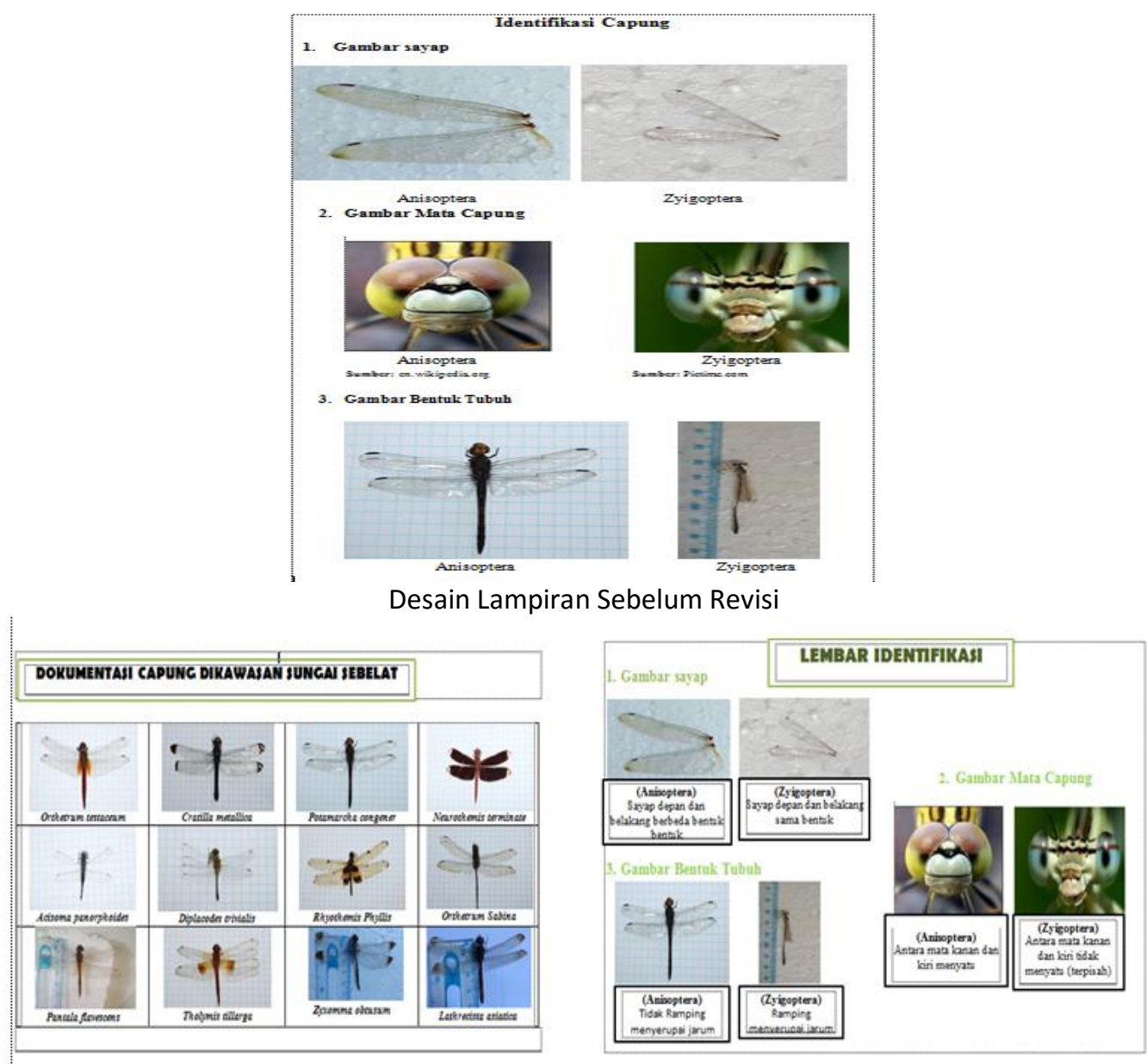

Desain Lampiran Setelah Revisi

Gambar 3. Perbaikan Lampiran Lembar Identifikasi

Kemudian LKPD hasil revisi tersebut di ujicobakan ke 27 peserta didik kelas $X$
IPA 2 SMA N 7 Bengkulu Utara. Tahapan ini dilakukan untuk melihat keefektifan 
dan kekurangan LKPD yang dikembangkan oleh peneliti, hal ini sesuai dengan Emzir (2012) yang berpendapat bahwa uji coba dilakukan untuk menguji dan melihat kekurangan dari LKPD serta melakukan revisi kembali agar dapat mencapai kompetensi dasar dan tujuan dalam kegiatan pembelajaran.

LKPD hasil pengembangan berdasarkan inventarisasi capung di kawasan Sungai Sebelat digunakan untuk mengukur keterampilan proses dasar peserta didik. Adapun aktivitas keterampilan proses dasar peserta didik diobservasi pada saat proses pembelajaran menggunakan LKPD berbasis hasil penelitian antara lain; mengamati, mengukur, menggolongkan, menyimpulkan dan mengkomunikasikan hasil pengamatan.

Hasil analisis keterampilan proses dasar peserta didik kelas X IPA ${ }^{2}$ SMA N 7 Bengkulu Utara dari 27 peserta didik dikelompokan menjadi 5 kelompok terdiri dari kelompok A, B, C, D dan E.
Berdasarkan data hasil belajar ranah keterampilan proses dasar diperoleh hasil pada kelompok B dan E mendapatkan predikat $B$, kelompok $A$ dan $D$ memperoleh predikat A- dan Kelompok C memperoleh predikat A. Penilaian keterampilan dilakukan oleh 2 orang pengamat terdiri dari guru Biologi kelas $X$ dan calon guru Biologi yang menggunakan lembar observasi beserta rubrik penilaian. Adapun ketuntasan minimal di kelas $X$ SMA N 7 Bengkulu Utara adalah 2,75 dengan predikat B-. Skor rerata klasikal hasil belajar keterampilan proses dasar peserta didik memperoleh skor lebih tinggi dibandingkan dengan KKM di kelas X SMA N 7 Bengkulu Utara, adapun persentase ketuntasan keterampilan dasar pada pembelajaran adalah $\geq 90 \%$ dengan nilai rerata 3,5 dan predikat $A-$-, sehingga secara keseluruhan berdasarkan hasil analisis keterampilan proses dasar peserta didik tuntas secara klasikal. Hasil analisis keterampilan proses dasar peserta didik dapat dilihat pada Tabel 4.

Tabel 4. Hasil Analisis Keterampilan Proses Dasar Peserta Didik

\begin{tabular}{cccc}
\hline Kelompok & Rata-rata Skor Pengamat & Nilai Rerata & Predikat \\
\hline A & 17,5 & 3,5 & A- \\
B & 15,5 & 3,1 & B \\
C & 20 & 4 & A \\
D & 19 & 3,8 & B \\
E & 15,5 & 3,1 & A- \\
Rata-rata Klasikal & & 3,5 & B- \\
Kriteria Ketuntasan Minimal Keterampilan & 2,75 & $\geq 90 \%$ \\
Persentase Ketuntasan & & \multicolumn{2}{c}{ Tuntas Secara Klasikal } \\
Kesimpulan & & \multicolumn{2}{c}{} \\
\end{tabular}

Dengan demikian pentinglah bagi seorang guru untuk mampu menguasai dan mengembangkan materi pelajaran, merencanakan, mempersiapkan, mengontrol dan mengevaluasi kegiatan peserta didik agar pembelajaran tersampaikan dengan baik dan tepat.

Berdasarkan Munandar (2015) yang menyimpulkan bahwa desain LKPD yang baik sangat dibutuhkan agar tercapainya proses pembelajaran yang mendorong peserta didik aktif dalam kegiatan pembelajaran. Selain dilakukan penilaian oleh observer yang terdiri dari guru Biologi dan calon guru Biologi, penilaian juga dilakukan berdasarkan pengerjaan pertanyaan yang terdapat di dalam LKPD. Hasil belajar ranah keterampilan proses 
dasar peserta didik dapat dilihat pada Tabel 5.

Tabel 5. Hasil Belajar Ranah Keterampilan Proses Dasar Peserta didik

\begin{tabular}{ccccc}
\hline \multirow{2}{*}{ Kelompok } & \multicolumn{3}{c}{ Rincian Penilaian } & NA \\
\cline { 2 - 4 } & $\begin{array}{c}\text { Tabel Pengamatan } \\
\text { (skor maks 30) }\end{array}$ & $\begin{array}{c}\text { Pertanyaan } \\
\text { (skor maks 35) }\end{array}$ & $\begin{array}{c}\text { Kesimpulan } \\
\text { (skor maks 35) }\end{array}$ \\
\hline A & 30 & 31 & 30 & 91 \\
B & 20 & 35 & 35 & 90 \\
C & 30 & 35 & 35 & 100 \\
D & 30 & 35 & 30 & 95 \\
E & 30 & 26 & 30 & 86 \\
Total Nilai & & & & 462 \\
Rata-rata & & & & 92,4 \\
Persentase & & & $92,4 \%$ \\
\hline
\end{tabular}

Berdasarkan Tabel 5 diketahui bahwa peserta didik mengerjakan LKPD secara berkelompok dengan rincian penilaian terdiri atas tabel pengamatan dengan skor maksimal 30, soal pertanyaan skor maksimal 35 dan kesimpulan dengan skor maksimal 35, dalam satu kelas terdapat 5 kelompok yaitu kelompok A, B, C, D dan E dimana secara berurutan memperoleh nilai akhir 91, 90, 100, 95 dan 86. Seluruh kelompok telah mampu mengerjakan LKPD dengan penilaian lebih dari $75 \%$. Penilaian LKPD dapat dikatakan tuntas apabila telah mencapai $\geq 75 \%$ dari skor persentase maksimal $100 \%$, ini menunjukan bahwa penggunaan LKPD dan model siklus $5 E$ serta penggunaan awetan kering capung (insektarium) dapat digunakan untuk mengukur keterampilan proses dasar peserta didik dalam mata pelajaran Biologi pada materi keanekaragaman hayati.

Dengan demikian dari hasil yang diperoleh dapat diketahui bahwa hampir seluruh peserta didik memiliki keterampilan proses dasar yang baik, sehingga dapat diartikan bahwa penggunaan LKPD dalam kegiatan pembelajaran dapat mengukur batas keterampilan proses dasar peserta didik kelas X IPA ${ }^{2}$ SMA N 7 Bengkulu Utara, hal ini sesuai dengan Trisna (2018) yang menyimpulkan bahwa pengetahuan dipandang sebagai sebuah tindakan yang bermakna untuk menanggulangi kendala psikologis, seperti pengabaian dan kesalahan informasi. Dalam kata lain meskipun pengetahun tidak memberikan efek langsung pada perilaku target, namun pengetahuan menjadi mekanisme tersendiri yang memberi fasilitas pada perubahan perilaku, hal ini sesuai dengan Ruyani (2009) yang mengatakan bahwa pengetahuan merupakan faktor penting dalam mengembangkan berberapa materi yang diajarkan.

Setelah proses pembelajaran berakhir, peneliti membagikan lembar angket uji keterbacaan kepada peserta didik yang berisi respon peserta didik terhadap proses pembelajaran pada materi keanekaragaman hayati menggunakan LKPD hasil pengembangan. Angket respon yang telah diisi oleh peserta didik dianalisis dan disajikan dalam Tabel 6. 
Tabel 6. Rekapitulasi Hasil Uji Keterbacaaan Peserta Didik SMA N 7 Bengkulu Utara Terhadap LKPD Hasil Pengembangan Keanekaragaman Capung di Kawasan Sungai Sebelat

\begin{tabular}{|c|c|c|c|c|c|}
\hline \multirow{3}{*}{ NO } & \multirow{3}{*}{ Respon } & \multicolumn{4}{|c|}{ Hasil } \\
\hline & & \multicolumn{2}{|c|}{ Yes } & \multicolumn{2}{|c|}{ Tidak } \\
\hline & & $\Sigma$ & $\%$ & $\Sigma$ & $\%$ \\
\hline & Aspek Desain/Kegrafisan & & & & \\
\hline 1 & $\begin{array}{l}\text { Desain sampul/cover LKPD ini bagus, sehingga membuat saya tertarik } \\
\text { untuk mempelajarinya }\end{array}$ & 27 & 100 & - & - \\
\hline 2 & $\begin{array}{l}\text { Pemilihan jenis huruf (font) sudah tepat sehingga memudahkan saya } \\
\text { dalam membacanya }\end{array}$ & 27 & 100 & - & - \\
\hline 3 & $\begin{array}{l}\text { Pemilihan ukuran huruf sudah tepat sehingga memudahkan saya dalam } \\
\text { membacanya }\end{array}$ & 25 & 92 & 2 & 0,07 \\
\hline 4 & $\begin{array}{l}\text { Penyajian tabel dalam LKPD ini disertai dengan keterangan yang jelas } \\
\text { dan dapat saya pahami }\end{array}$ & 27 & 100 & - & - \\
\hline 5 & $\begin{array}{l}\text { Penyajian gambar dalam LKPD ini disertai dengan keterangan yang jelas } \\
\text { dan dapat saya pahami. }\end{array}$ & 27 & 100 & - & - \\
\hline 6 & $\begin{array}{l}\text { Tata letak (lay out) dalam LKPD ini sangat menarik sehingga membuat } \\
\text { saya nyaman dalam mempelajarinya } \\
\text { Aspek Bahasa }\end{array}$ & 27 & 100 & - & - \\
\hline 7 & Bahasa yang digunakan dalam LKPD ini jelas & 27 & 100 & - & - \\
\hline 8 & Bahasa yang digunakan dalam LKPD ini sederhana & 27 & 100 & - & - \\
\hline 9 & Bahasa yang digunakan dalam LKPD ini mudah saya pahami & 27 & 100 & - & - \\
\hline 10 & Bahasa yang digunakan dalam LKPD ini tidak bermakna ganda/ambigu & 27 & 100 & - & - \\
\hline 11 & $\begin{array}{l}\text { Bahasa yang digunakan dalam LKPD ini tidak membuat saya bingung } \\
\text { dalam memaknai }\end{array}$ & 25 & 92 & 2 & 0,07 \\
\hline \multirow[t]{2}{*}{12} & $\begin{array}{l}\text { Istilah-istilah Biologi dalam LKPD ini memiliki penjelasan yang jelas } \\
\text { sehingga tidak membuat saya bertanya-tanya }\end{array}$ & 25 & 92 & 2 & 0,07 \\
\hline & Aspek Pelaksanaan & & & & \\
\hline 13 & $\begin{array}{l}\text { Kegiatan dalam LKPD ini memberikan saya pengalaman langsung belajar } \\
\text { mengahadapi objek belajar }\end{array}$ & 27 & 100 & - & - \\
\hline 14 & Semua kegiatan dalam LKPD ini mampu saya laksanakan & 24 & 89 & 3 & 0,11 \\
\hline 15 & $\begin{array}{l}\text { Peralatan yang digunakan dalam LKPD ini semuanya dibutuhkan selama } \\
\text { kegiatan }\end{array}$ & 27 & 100 & - & - \\
\hline 16 & $\begin{array}{l}\text { Peralatan yang digunakan dalam LKPD ini semuanya mudah untuk } \\
\text { digunakan }\end{array}$ & 27 & 100 & - & - \\
\hline 17 & Persoalan diskusi dalam LKPD ini mampu saya selesaikan & 26 & 96 & 1 & 0,04 \\
\hline \multirow[t]{2}{*}{18} & Persoalan tugas dalam LKPD ini mampu saya selesaikan & 27 & 100 & - & - \\
\hline & Aspek kemandirian & & & & \\
\hline 19 & $\begin{array}{l}\text { Petunjuk penggunaan LKPD ini membuat saya paham apa yang harus } \\
\text { saya lakukan }\end{array}$ & 27 & 100 & - & - \\
\hline 20 & $\begin{array}{l}\text { Prosedur kerja tiap kegiatan jelas sehingga saya paham dengan apa } \\
\text { yang harus saya lakukan pada setiap kegiatan }\end{array}$ & 26 & 96 & 1 & 0,04 \\
\hline 21 & $\begin{array}{l}\text { Prosedur kerja tiap kegiatan mudah dipahami sehingga saya paham } \\
\text { dengan apa yang harus saya lakukan pada setiap kegiatan }\end{array}$ & 27 & 100 & - & - \\
\hline 22 & $\begin{array}{l}\text { Kegiatan-kegiatan dalam LKPD ini menuntut saya untuk bekerja dengan } \\
\text { kelompok }\end{array}$ & 27 & 100 & - & - \\
\hline 23 & $\begin{array}{l}\text { Kegiatan-kegiatan dalam LKPD ini menuntut saya untuk mencari } \\
\text { informasi secara mandiri tanpa bergantung pada guru } \\
\text { Aspek Manfaat }\end{array}$ & 27 & 100 & - & - \\
\hline 24 & $\begin{array}{l}\text { LKPD ini memberikan gambaran kepada saya bahwa belajar Biologi itu } \\
\text { menyenangkan. }\end{array}$ & 27 & 100 & - & - \\
\hline 25 & LKPD ini menjadikan saya lebih mengenal lingkungan sekitar. & 27 & 100 & - & - \\
\hline 26 & LKPD ini menjadikan saya lebih mencintai lingkungan sekitar & 27 & 100 & - & - \\
\hline 27 & LKPD ini menambah kesadaran saya tentang potensi keberadaan & 27 & 100 & - & - \\
\hline
\end{tabular}




capung di sekitar kita
$\begin{aligned} & \text { LKPD ini menambah kesadaran saya tentang ancaman keberadaan } \\ & \text { capung di sekitar kita }\end{aligned}$
$\begin{aligned} & \text { LKPD ini memotivasi saya untuk ikut serta dalam melestarikan } \\ & \text { Keanekaragaman Hayati Indonesia }\end{aligned}$
$\begin{aligned} & 27 \\ & \text { Jumlah Rata-rata Persentase } \\ & \text { Kategori }\end{aligned}$

Berdasarkan Tabel 6 diketahui bahwa kriteria LKPD yang direspon oleh peserta didik mendapatkan kategori "Sangat Baik" dengan persentase 98,5\%, hasil analisis menunjukkan bahwa hampir seluruh kriteria mendekati skor respon $100 \%$ dari 27 peserta didik, karena terdapat 5 kriteria $(3,11,12,17$ dan 20) dari 29 kriteria yang tidak merespon positif sehingga diperoleh skor respon 98,5\% dari 27 peserta didik, Berikut ini beberapa komentar dan saran peserta didik mengenai LKPD antara lain; pembelajaran yang telah dilakukan sangat menarik, memudahkan mempejalari keanekaragaman hayati, dan dapat mendorong peserta didik untuk aktif mencari informasi. Selain itu, terdapat penilaian hasil kinerja peserta didik pada tabel pengamatan, pertanyaan dan kesimpulan yang dilakukan secara diskusi kelompok. Penilaian ini juga berguna untuk melihat apakah LKPD yang dibuat dapat dikerjakan dan sesuai dengan kemampuan peserta didik.

Penelitian ini sesuai dengan Fajri (2018) dimana hasil analisis respon peserta didik terhadap kegiatan pembelajaran yang menggunakan bahan ajar berupa LKPD pada materi vertebrata memperoleh respon sangat baik hal ini dikarenakan proses pembelajaran menggunakan bahan ajar berupa LKPD yang berbasis penelitian mampu memberikan hal yang baru bagi peserta didik, hal ini sesuai juga dengan Wulansari (2013) mengatakan bahwa pembelajaran dengan menggunakan bahan ajar LKPD mampu manarik minat belajar peserta didik dan memberikan latihan belajar menemukan konsep dari pengamatan yang dilakukan. Kegiatan yang tersusun dari bersifat konkret menuju abstrak lebih memudahkan peserta didik memahami materi dan menemukan konsep.

\section{PENUTUP}

\section{Simpulan}

Berdasarkan hasil validasi kelayakan LKPD oleh tiga validator serta validasi uji keterbacaan pada peserta didik kelas X IPA 2 SMA N 7 Bengkulu Utara hasil validasi dari 3 validator memperoleh persentase rerata $88 \%$ dan aspek dan untuk uji keterbacaan didapatkan persentase ideal 98,5\% masuk ke dalam kategori sangat baik. Untuk keterampilan proses dasar peserta didik materi keanekaragaman hayati mencapai ketuntasan klasikal dengan nilai rerata 3,5 dan predikat APembelajaran mengunakan LKPD berbasis penelitian dapat dikatakan berhasil karena persentase ketuntasan keterampilan $\geq 90 \%$.

\section{Saran}

Penelitian selanjutnya diharapkan mengimplementasikan LKPD yang telah didesain di dalam kelas.

\section{DAFTAR PUSTAKA}

Anas, Sudijono. 2012. Pengantar Evaluasi Pendidikan. Jakarta : Raja Grafindo Persada.

Asy'ari, Malischa. 2006. Penerapan Pendekatan Sains-Teknologi Masyarakatdalam 
Pembelajaran Sains di Sekolah Dasar. Yogyakarta : Universitas Sanata Dharma.

Emzir. 2012. Metodologi Penelitin Pendidikan Kuantitatif dan Kualitatif. Bandung : Rajagrafindo persada

Fajri. A., Abdul.R., Ariefa. P.Y. 2018. Pengembangan Lembar Kerja Peserta Didik Materi Vertebrata Kelas $X$ Berdasarkan Invetarisasi Ikan Laut. Diklabio 2 (2) : 52-57.

Majid. 2009. Perencanaan Pembelajaran Mengembangkan standar Kompetensi Guru. Bandung : PT Remaja Rosdakarya.

Munandar, Haris., Yusrizal., Mustanir. 2015. Pengembangan Lembar Kerja Peserta Didik (LKPD) Berorientasi Nilai Islam pada Materi Hidrolisis Garam. JPSI 3(1) : 27-37.

Peraturan Menteri Pendidikan dan Kebudayaan Republik Indonesia Nomor 104 Tahun 2014 Tentang Penilaian Hasil Belajar oleh Pendidik pada Pendidikan Dasar dan Pendidikan Menengah. Jakarta : Permendikbud.

Riduwan. 2015. Pembelajaran Saintifik untuk implementasi Kurikulum 2013. Jakarta : Bumi Aksara.

Rosalia.R., Ariefa.P.Y., Kasrina. 2017. Pengembangan LKS Berdasarkan Hasil Studi Identifikasi Jenis Bambu di Desa Harapan Makmur. Diklabio 1 (1) : 93-102.

Ruyani. A. 2010. Intergrating The Message Of Turtle Concervation Into a Science
Teaching Plan For Elementary School In Bengkulu City. Asian Turtle Conservation Network.

Sanjaya, P. 1970. Dasar-Dasar Ekologi Serangga. Bogor: IPB

Shelly, A.A., Sri, R., Ariefa. P.Y. 2017. Penerapan Model Pembelajaran Inkuiri untuk Meningkatkan Keterampilan Proses Sains Siswa Kelas VIII.1. Diklabio 1 (1) : 103-108.

Trianto. 2012. Model Pembelajaran Terpadu. Jakarta : PT. Bumi Aksara

Trisna, D.M., Aceng.R., Yennita. 2018. Pengembangan Lembar Kerja Peserta Didikuntuk Menilai Kecenderungan Berperilaku Konservasi Kura-Kura. Diklabio 2 (2) : 102-107.

Widarmayanti, R.P., Susantini, E., Ambarwati, R. 2015. Profil Validitas LKS Berbasis Keterampilan Proses pada Sub-Pokok Bahasaan Invertebrata Untuk SMA. Jurnal Bioedu. 4 (1) : 2302-9528.

Widjajanti, E. P. 2008. Pelatihan Penyusunan LKPD Mata Pelajaran Kimia Berdasarkan Kurikulum Tingkat Satuan Pendidikan Bagi Guru SMA/SMK. Yogyakarta : FMIPA UNY.

Wulansari, Shella Dyah. 2013. Peningkatan Aktifitas Dan Hasil Belajar Matematika Melalui Model Cooperative Learning Tipe Two Stay Two Stray Dengan Media Grafis Pada Siswa Kelas IV A SDN 2 Langkapura Tahun Pelajaran 2013/2014. Lampung : Universitas lampung. 